\title{
EVALUATION OF THE IMPACT OF OIL SPILLAGE ON IZOMBE COMMUNITY AND THEIR PRODUCTIVITY IMPLICATIONS
}

\author{
Osueke G. O' ${ }^{1}$, Emeka-Opara F. $\mathrm{O}^{2}$ \\ ${ }^{1}$ Mechanical Engineering Dept.; Federal University of Technology, Owerri \\ ${ }^{2}$ National Productivity Centre, Abuja. Nigeria
}

\begin{abstract}
This project reviewed the environmental impact study of oil spillage, using the case study of Izombe in Imo State, Nigeria. It critically analysed the effects of oil spillage on marine life, land, ecological effect, and the effect on human health. It further treated the socio-economics of the people and appraised sustainable environment and development which only can be achieve through environmental impact assessment (EIA). The research also involved the use of primary and secondary sources of data collection for methodology. Questionnaires were developed, administered and observations recorded. We found out that oil spillage occurred up to two (2) times yearly at Izombe, thereby reducing the likelihood of any productivity improvement. It was traced mainly due to sabotage of oil installation. We found out that $56.4 \%$ of oil spillage was due to sabotage. We recommended increased efforts by the stakeholders in the management of the oil installations.
\end{abstract}

Keywords: Evaluation, Oil spillage, Productivity, Izombe.

\section{INTRODUCTION}

Oil spillage is a major environmental problem associated with oil exploration activities. This has led to very serious pollution and destruction of flora, Fauna and resort centers. It has also caused pollution of drinkable water destruction of properties and lives along the Nigerian coast (Ayaweip, 2000). It is the cause of major regional crisis in the Niger Delta. Factors responsible for oil spillage in the zone are: Corrosion of oil pipes and tanks, sabotage, port operation and inadequate care in oil production operations and Engineering drills. The use of oil from petroleum for artificial lighting was oil's springboard to fame.

Shell D Arcy struck its first oil well at Iho, 16 kilometers North East of Owerri, Imo State in 1954, even though it was found to be dry well, in 1956 they found their first oil well of commercial quantity at Oloibiri in Ogba Local Government Area of the then Rivers State and now Bayelsa State. Shell then started oil production in Oloibiri in Ogbia Local Government Area in 1958. The progress made by shell, motivated other companies to propose exploration in Nigeria. By 1961, Nigerian AGIP Oil company (NAOL), MOBIL, Sofrab (now ELF). Benneth A. (2009) Tenneco (also Texaco and most recently Cornoil), Amoseas (now chevron) all started oil exploration in the Onshore and Offshore area of Nigeria territory.

This increase in the exploration and production of oil in Nigeria account for $80 \%$ of the nation's foreign exchange earning Worika, (2001). In 1958 the production of 5,140 barrels per day was doubled to 11,220 barrels per day in 1959, others are 6,367,188 barrels in 1960, 99,353,794 barrels in 1985 Olarufumi (2003) Nest (1999), Nigeria crude oil production average 2.118 million barrels per day in 2002 and 2.2million barrels per day in 2004 .
The production of oil in Nigeria multiplied over the years due to increase in world price of oil and in meet the over increasing energy need of the population presently, there are seventeen (17) oil producing companies in Nigeria, six of which are classified as major (shell, mobile, chevron Texaco now Conoil Agip and Total final ELF) AND A good number of other prospecting and exploring companies. The federal Government of Nigeria, represented by (NNPC) has $55 \%$ equity share in the joint venture operation with the multinational oil producing group while 45 percent shares get to the rest joint ventures partners.

\subsection{Statement of Problem}

Since the discovering of oil in Nigeria in the 1950s, the country has been suffering the negative environmental consequences of oil development. The growth of the country's oil industry, combined with a population explosion and lack of effective environmental regulations, led to substantial damage to Nigeria's environment especially in the Niger Delta region, the center of the country's oil industry.

Oil spill pose a major threat to the environment in the Niger Delta Region. If not checked or effectively managed, it could lead to total annihilation of the ecosystem in the Niger Delta Region where oil spills have become prevalent by killing the farm crops in the region and aquatic lives, since farming and fishing are the common occupations for the Niger Delta region people. 


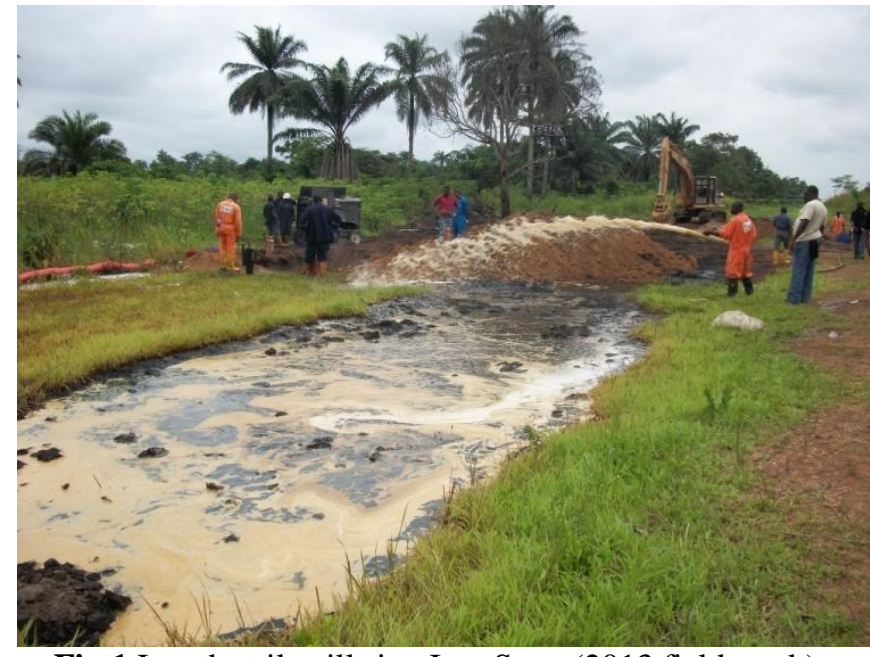

Fig 1 Izombe oil spill site, Imo State (2013 field work)

Productivity drop and life in this region are increasingly becoming unbearable due to the effects of oil spills and many communities continues to groan under the degrading impacts of oil spills, Oyem (2001). In the Nigeria coastal environment, large areas of the mangrove ecosystem have been destroyed. The mangrove was once a source of both fuel woods, for indigenous people and a habitat for the area's biodiversity, but now the oil toxicity has depleted and devitalized the ecology. Oil spill also has adverse effect on marine life, which has been contaminated, in turn having negative consequence for human health from consuming contaminated seafood. Oil spill has also destroyed farmlands, polluted ground and drinkable water and caused drawbacks in fishing in the coastal area.

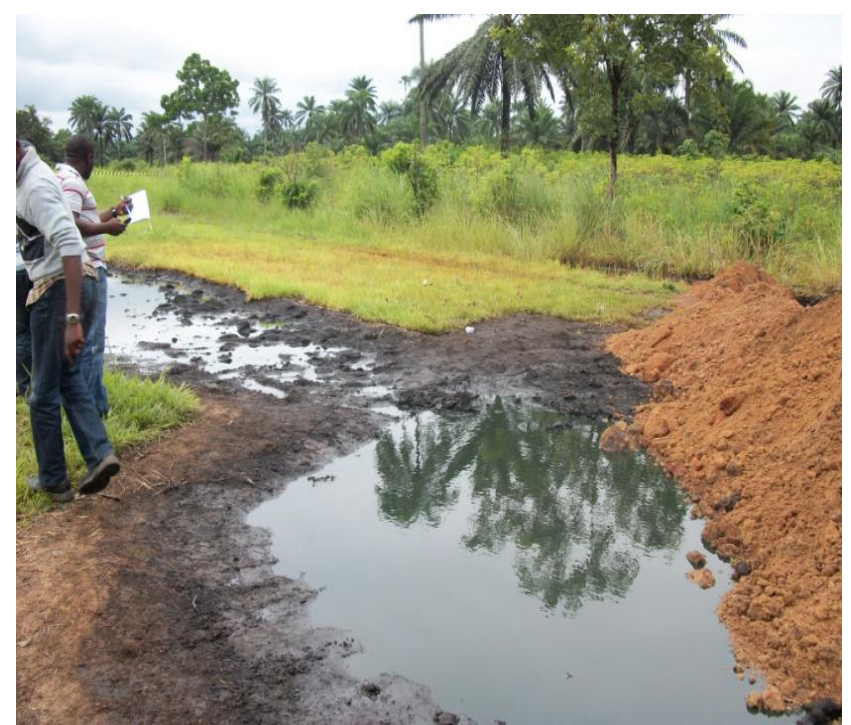

Fig 2 Oil spill site in Izombe farm land (2013)
Oil spills in the Niger Delta have been a regular occurrence, and the resultant environmental degradation of the surrounding environment has caused a significant tension between the people living in the region and the multinational oil companies operating there. It is only in the past decade that environmental group, the Nigeria Federal government and the foreign oil companies which extract oil in the Niger Delta have begun to take steps to mitigate the damage. According to Eco-Impact (2011), the harmful effects of oil spill on the environment are many.

\subsection{Objectives of Study}

The objectives of this study are to examine the effect of oil spillage on Izombe in Imo State and its environs. This also include: to identify the causes of oil spillages in the study area; to identify the frequency of occurrence of oil spillage within the study area; to evaluate the impact, effect and remediation of oil spillage on the environment; and to recommend appropriate solutions to oil spillage in the environment.

\section{RESEARCH METHODOLOGY}

In carrying out this study, we used primary data collection such as administering of questionnaire, observation, personal interviews, discussion with indigenes of communities in the area and the oil company operators. Secondary source of data involves review of related literatures on how oil spillage had affected the people and infrastructural development in the land. 


\subsection{Results and Data Analysis}

\subsubsection{Results}

Table 1 showing the sex of the respondents

\begin{tabular}{|l|l|l|l|}
\hline Settlement & Male & Female & Total \\
\hline Umuekwesi & 3 & 2 & 6 \\
\hline Umunwatu & 4 & 2 & 6 \\
\hline Umuokum & 5 & 1 & 6 \\
\hline Umuobia & 6 & - & 6 \\
\hline Izombe & 4 & 2 & 6 \\
\hline Total & 22 & 8 & 30 \\
\hline Percentage & $73.3 \%$ & $26.7 \%$ & $100 \%$ \\
\hline
\end{tabular}

Table 2 shows the age distribution of respondents

\begin{tabular}{|c|c|c|c|c|c|}
\hline Settlement & $15-30 y r$ & 31-40yrs & 41-60yrs & $\begin{array}{ll}61 & \text { and } \\
\text { above } & \end{array}$ & Total \\
\hline Umuekwesi & 6 & - & - & - & 6 \\
\hline Umunwatu & 5 & - & 1 & - & 6 \\
\hline Umuokum & 2 & 1 & 3 & - & 6 \\
\hline Umuobia & 3 & 2 & 1 & - & 6 \\
\hline Izombe & - & 3 & 2 & 1 & 6 \\
\hline Total & 16 & 6 & 7 & 1 & 30 \\
\hline Percentage & $53.3 \%$ & $20 \%$ & $23.3 \%$ & $3.3 \%$ & $100 \%$ \\
\hline
\end{tabular}

Table 3 Shows occupation of the respondents

\begin{tabular}{|l|l|l|l|l|l|}
\hline Settlement & Trading & Teaching & Farming & Unemployed & Total \\
\hline Umuekwesi & - & 5 & 1 & - & 6 \\
\hline Umunwatu & 2 & 1 & - & 3 & 6 \\
\hline Umuokum & 1 & 3 & 2 & - & 6 \\
\hline Umuobia & 3 & 1 & 2 & - & 6 \\
\hline Izombe & 1 & 2 & 1 & 2 & 6 \\
\hline Total & 7 & 12 & 6 & 5 & 30 \\
\hline Percentage & $23.3 \%$ & $40 \%$ & $20 \%$ & $16.7 \%$ & $100 \%$ \\
\hline
\end{tabular}

Table 4 shows the causes of oil spillage

\begin{tabular}{|l|l|l|l|l|}
\hline Settlement & Sabotage & leakage & fault & Total \\
\hline Umuekwesi & 5 & 1 & - & 6 \\
\hline Umunwatu & 2 & 3 & 1 & 6 \\
\hline Umuokum & 4 & 2 & - & 6 \\
\hline Umuobia & 1 & 5 & - & 6 \\
\hline Izombe & 2 & 3 & 1 & 6 \\
\hline Total & 14 & 14 & 2 & 30 \\
\hline Percentage & $46.7 \%$ & $46.7 \%$ & $6.6 \%$ & $100 \%$ \\
\hline
\end{tabular}

\subsubsection{Data Analysis}

From table 1 above, the majority of respondents were males $(73 \%)$. All the target audiences were adults, as in table II. However, $53 \%$ of the adults were in the age of range 1530years.

From table III, it shows that $40 \%$ of the respondents are teachers and these are mainly primary and secondary school teachers. $23.3 \%$ and $20 \%$ of the people in the target area are engaged in trading and farming respectively. Only about $16.7 \%$ are unemployed.

\section{CONCLUSION AND RECOMMENDATION}

\subsection{Conclusion}

Based on the finding, it will be said that oil spillage is the major problem of the environment as a result of oil exploration activities. Every settlement in the area under study has experienced this ugly incident. This incident occurs frequently within the area, it was related that incident has occurred at least ten times between 2005 till date in the study area. Pipeline leakage is the most experienced cause of this incident. The aquatic ecosystem; rivers fish ponds 
and mangrove vegetation etc are facing degradation as a result of the incident. The rivers and creeks of the area are no longer good and fit for domestic activities due to the constant pollution of oil spillage. It has become unfit for the survival of aquatic life as a result of the incident in the area which has also brought about a reduction of fish and other seafood to human in the area and also retardation of farm crops and total productivity of the areas.

\subsection{Recommendation}

There is urgent need for government to review the mining laws of Nigeria to enable the oil communities benefit from the exploitation. The oil communities should be compensated.

Children of those in the oil communities should be provided with the means to acquire education to enable them to be more productive.

\section{REFERENCES}

[1] Ayaweip., 2000. Spills in the Niger Delta. Urhobo historical society.

[2] Benneth A.A. 2009 Oil spill and the environment. Proceeding of the petroleum Industry and the Nigeria Environment N.N.P.C Lagos.

[3] Eco- impact, (2001); Vol. 1 No 7 page 2, and 7 published by ND-HERO.

[4] Idoniboye, B.E. The impact of oil exploration on The aquatic environment:

[5] Ishikaku E.C.(2004); The impact of all exploration on the host communities. Nest, (1999); Nigerian threatened Environment.

[6] Nwoojuku, C.A. (2008);“Oil spill and the environment" proceeding on the international seminar on the petroleum industry and the environment, N.N.P.C Lagos geographical perspective on Ofomata, G.E.K and Okocha S.A. (2000); "Environmental problem of the Nigeria Delta and their consequences" in Osuntokun (EDO) Environmental problems of the Niger delta Gredrich Ebert foundation Lagos, Nigeria. 